\title{
Effect of the COVID-19 Pandemic on Eating Habits and Food Purchasing Behaviors of University Students
}

\author{
Hacı Ömer Yılmaz ${ }^{*}$, Ramazan Aslan², Cihan Unal
}

\begin{abstract}
${ }^{1}$ Department of Nutrition and Dietetics, Faculty of Health Science, Gümüşhane University, Turkey
${ }^{2}$ Department of Emergency and Disaster Management, Faculty of Health Science, Gümüşhane University, Turkey

${ }^{3}$ Department of Healthcare Management, Faculty of Health Science, Gümüşhane University, Turkey
\end{abstract}

\begin{abstract}
COVID-19 disease, which has spread rapidly all over the world since the first case was detected in December 2019, has become the primary focus in every country. Radical measures have been taken by governments to prevent the spread of the disease. Precautions and social rules have required drastic changes to daily life activities everywhere. University students who have had to interrupt their educations are one of the affected groups by this disease sociologically, psychologically and physiologically. The aim of this study was planned and conducted to determine the effect of COVID-19 on university students' eating habits and food purchasing behaviors. The study was completed in April 2020 with 866 university students studying and training at the Faculty of Health Sciences, Gümüşhane, Turkey. Research data was obtained by online questionnaire. The questionnaire was prepared with information obtained from a literature review and the opinions of experts. It included questions about eating habits and food purchasing behaviors. The basic result of the study was that COVID-19 disease has caused significant changes in the eating habits and food purchasing behaviors of university students. Primarily, they now paid greater attention to hygiene when food purchasing, and had increased their consumption compared to previously, since they were now home 24 hours a day, seven days a week.
\end{abstract}

Keywords: COVID-19, eating habits, food purchasing, Turkey, university students

\section{Introduction}

The World Health Organization (WHO) China Country Office started reporting pneumonia cases of unknown etiology in Wuhan City, Hubei Province, China on December 31, 2019. ${ }^{1}$ One week later, on January 7, the biological agent causing the condition was defined as a new type of coronavirus (2019-nCoV) that had not previously been detected. ${ }^{2}$ Subsequently, the disease caused by 2019-CoV was named COVID-19. In Turkey, the first official COVID-19 death was announced on March 10. The next day, WHO declared the disease a pandemic. ${ }^{3}$ The $2019-\mathrm{nCoV}$ belongs to the $\beta$-coronavirus family, which includes severe acute respiratory syndrome coronavirus (SARS-CoV) and Middle East respiratory syndrome coronavirus (MERS-CoV). The mortality rates of SARS-CoV and MERS-CoV are $11 \%$ and $35 \%-50 \%$, respectively, while the mortality rate of the COVID-19 virus is about $3.4 \%$ according to currently available data. ${ }^{4}$ The disease is spread by respiratory droplets from positive persons landing in neighbors' mouths, eyes and noses. COVID-negative persons who touch infected sur-

Correspondence*: Hacı Ömer Yllmaz, Department of Nutrition and Dietetics, Faculty of Health Science, Gümüşhane University, Health Science Building 3rd Floor, Campus Center,Turkey, E-mail: hcmrylmz@hotmail.com, Phone: +90 542270-1975 faces and then their faces can infect themselves. ${ }^{5}$ More recently, scientists have pointed to small droplets lingering in the air, especially in enclosed rooms, even after people have left. 6

Nutrition is a basic requirement of life. Eating habits and behaviors can be affected by sociological, psychological, and physiological factors. ${ }^{7}$ The elevation of COVID-19 to pandemic status has affected all of those; the high rate of spread has caused behavioral changes in people, such as eating habits. Other behaviors may be affected because the subject of COVID-19 now constitutes an immense part of the world's agenda. In Turkey, the government has taken radical measures to prevent the spread of the virus. It discloses daily the number of cases through numerous media channels, along with explanations of predictions by experts. Organizations such as WHO and the American Centers for Disease Control and Prevention (CDC), along with healthcare professionals like physicians and dieticians, have made nutritional recommendations to promote adequate and balanced meals that support the immune system, one of the de- 
fenses against COVID-19.8,9 Many studies have determined that university students lack adequate and balanced meals due to their separation from their families, insufficient funds, or lack of time and information about healthy nutrition. ${ }^{10-12}$ In as much as university students, the sample group for our study comprises one of the most psychologically and sociologically affected groups, the Republic of Turkey Higher Education Council decided to conduct distance education instead of face-to-face for the remainder of the 2019-2020 academic year. After this decision, students were forced to stop their classes and nearly all of them went home to their families or hometowns. ${ }^{13}$ In light of this information, the aim of this study is to determine and assess how the COVID-19 outbreak has altered the eating habits and food purchasing behaviors of university students.

\section{Method}

The study used cross-sectional design. The study sample consisted of 2,692 students training in the Spring Semester, Academic Year 2019-2020, at the Faculty of Health Sciences, Gümüşhane University. The data collected online on April 5-6, 2020 (Google Forms). A questionnaire method used to collect data. The questionnaire created by the researchers through literature review and opinions of experts to determine changes in the eating habits of the participants during the COVID-19 pandemic period. It consisted of a total of 39 questions, six of which were demographic information and 33 of which were aimed at determining changes in eating habits and food purchasing behaviors. Behavioral scoring was employed for both. Both behaviors were rated as +1 point for increased, 0 points for no change, and -1 point for decreased. The eating habits score ranged from -11 to +11 , while the food purchasing behavior score ranged from -10 to +10 . A positive score indicated a positive change in behaviors.

Eating habits consisted of packaged food consumption and physical activity level items, while food purchasing behaviors included ordering meals from outside.

The computer statistic program was used to analyze the data. Percentage, frequency, number (n), mean, standard deviation (SD), and percentage values $(\%)$ were given as descriptive statistics. Student t-tests were used to determine statistical differences between the two groups. Significance level was accepted as p-value $<0.05$. Written informed consent was obtained from all participants before the study began. All procedures were conducted in accordance with the ethical standards of the 1964 Helsinki Declaration.

\section{Results}

A total of 960 people completed the questionnaire. The carelessly-filled forms identified by excluding the re- verse question. A total of 866 forms analyzed. The gender of the participants were 677 females $(78.2 \%)$ and 189 males $(21.8 \%)$. The mean age of the students was $21.2 \pm$ 1.4 years, height was $165.4 \pm 10.0 \mathrm{~cm}$, and weight was $60.8 \pm 11.4 \mathrm{~kg}$. Body mass index (BMI) was $23.9 \pm 11.2$ $\mathrm{kg} / \mathrm{m}^{2}$. The student majors were health management $(35.1 \%)$ and nursing department $(18.0 \%) ; 26.1 \%$ were in the 2 nd grade, $27.9 \%$ were in the 4 th grade. Of those, $92.1 \%$ were not diagnosed with any chronic diseases. Some of the findings include:

1. When some of the student eating habits were examinmined, it was determined that $58.3 \%$ consumed two main meals per day and $43.9 \%$ consumed one snack meal before COVID-19. During the COVID-19 pandemic, $23.0 \%$ of the students reported an increase in the number of meals and $38.0 \%$ of the snacks;

2. Approximately $11.5 \%$ of the students stated that someone in their close social environment had been diagnosed with COVID-19 (Table 1);

3. While $24.9 \%$ of the students declared that they smoked before COVID-19, this rate decreased to $15.8 \%$ with COVID-19. The rate of those who said they would smoke again when the concern of the disease disappears was $16.7 \%$.

4. Responses regarding alcohol use were similar to smoking. While the rate of those who consumed alcohol before COVID-19 was $10.6 \%$, it decreased to $6.6 \%$ with COVID-19. The rate of those who said they would use it again when the concern of the disease disappeared was only $8.5 \%$ (not shown).

With regard to the use of nutritional supplements, $81.9 \%$ of the students declared that they had never used them before COVID-19, 11.2\% had used vitamin D, and $8.2 \%$ used vitamin B12. Now, during the COVID-19 pandemic period, the rate of those who did not use any nutritional supplements was $90.3 \%$, the rate of those using vitamin $\mathrm{D}$ was $5.2 \%$, and those using vitamin B12 were $4.0 \%$ (Table 2 ). Nearly $60 \%$ stated that they used nutritional supplements on the recommendation of their doctors, $32.4 \%$ used them on their own judgment, and the remainder used them on the advice of close friends or family (not shown).

With regard to the statement, "An adequate and balanced diet is important for COVID-19 disease, not a single food," $78.8 \%$ of respondents agreed. In addition, $6.9 \%$ believed garlic alone could cure COVID-19 disease. Another $4.0 \%$ put their faith in red, yellow, and orange-colored fruits and vegetables (Table 3 ).

During the COVID-19 pandemic period, participants believed in the virus-repellent properties of increased water consumption $(36.8 \%)$, vegetables $(40.5 \%)$, fruits $(49.1 \%)$, red meat, chicken and fish $(32.1 \%)$, dairy products $(41.0 \%)$, attention to adequate and balanced nutrition $(46.3 \%)$, decreased consumption of packaged 
Table 1. Demographic Information and Eating Habits of the Participants

\begin{tabular}{llrr}
\hline Characteristic & Category & n & $\%$ \\
\hline Sex & Male & 189 & 21.8 \\
Department & Female & 677 & 78.2 \\
& Emergency and disaster management & 134 & 15.5 \\
& Nutrition and dietetic & 145 & 16.7 \\
& Nursing & 156 & 18.0 \\
& Occupational health and safety & 44 & 5.1 \\
& Healthcare management & 304 & 35.1 \\
Grade & Social work & 83 & 9.6 \\
& 1 & 156 & 18.1 \\
& 2 & 226 & 26.1 \\
Chronic disease & 3 & 242 & 27.9 \\
\multirow{2}{*}{ Mean meal } & 4 & 242 & 27.9 \\
& Yes & 68 & 7.9 \\
Snacks & No & 798 & 92.1 \\
& 1 & 4 & 0.5 \\
\multirow{2}{*}{ Main meal in COVID-19 pandemic } & Increased & 505 & 58.3 \\
& 2 & 357 & 41.2 \\
Snacks in COVID-19 pandemic & Not changed & 380 & 43.9 \\
& Decreased & 373 & 43.1 \\
Diagnosed who COVID-19 in the & Increased & 113 & 13.0 \\
social environment & Not changed & 199 & 23.0 \\
& Yecreased & 615 & 71.0 \\
& No & 52 & 6.0 \\
& 2 & 329 & 38.0 \\
& & 498 & 57.5 \\
& & 39 & 4.5 \\
& & 100 & 11.5 \\
& & 766 & 88.5 \\
\hline
\end{tabular}

Table 2. Nutritional Supplement Usage by Participants before and during COVID-19

\begin{tabular}{lrrrr}
\hline \multirow{2}{*}{ Supplement } & \multicolumn{2}{c}{ Before COVID-19 } & \multicolumn{2}{c}{ During COVID-19 } \\
\cline { 2 - 5 } & \multicolumn{1}{c}{$\mathbf{n}$} & $\%$ & $\mathbf{n}$ & $\%$ \\
\hline Not used & 709 & 81.9 & 782 & 90.3 \\
Vitamin B12 & 72 & 8.3 & 35 & 4.0 \\
Vitamin C & 28 & 3.2 & 40 & 4.6 \\
Iron & 12 & 1.4 & 12 & 1.4 \\
Vitamin D & 97 & 11.2 & 45 & 5.2 \\
Folic acid & 13 & 1.5 & 12 & 1.4 \\
Omega-3 & 24 & 2.8 & 9 & 1.0 \\
Propolis & 6 & 0.7 & 4 & 0.5 \\
\hline
\end{tabular}

products $(54.3 \%)$, and physical activities $(31.9 \%)$ (Table 4).

Food purchasing behaviors of the participants were assessed during the COVID-19 pandemic period. According to the data, respondents bought more food at one time $(64.4 \%)$, used gloves while buying food $(80.0 \%)$, cleaned all food packages with a wet napkin $(70.4 \%)$, made pastries at home $(69.9 \%)$, and bought less packaged food $(70.8 \%)$ (Table 5$)$.

There was a positive increase in participant eating habits and food purchasing behaviors. If there were no change in either, the mean score would be expected to be 0 (zero). Females' behavior score was higher than males' both behaviors. It was statistically significant in food purchasing behaviors score (Table 6).
Table 3. Participants' Beliefs about Foods that Prevent COVID-19

\begin{tabular}{lrr}
\hline Thoughts & n & $\%$ \\
\hline Adequate and balanced diet is important, not a single food & 682 & 78.8 \\
Garlic & 59 & 6.9 \\
Yellow, red, and orange-colored fruits and vegetables & 35 & 4.0 \\
Vinegar & 33 & 3.8 \\
Yogurt, kefir, etc. & 19 & 2.2 \\
Sumac & 17 & 2.0 \\
Giblets & 17 & 2.0 \\
Turmeric & 4 & 0.5 \\
\hline
\end{tabular}

\section{Discussion}

The spread of COVID-19 disease in Turkey and the world has caused significant changes in both the nutritional and food purchasing behaviors of university students. In response to recent questionnaires, the majority of students declared that they have increased the number of their meals and snacks during the pandemic period, compared to their previous habits. We thought to be due to university students paying more attention to their diets to ward off disease. However, it may also be attributed to more time available for eating because they are with their families and their educations have been interrupted. A similar situation exists with alcohol and smoking.

In general, the use of nutritional supplements by university students has decreased during the pandemic period. We thought that this is due to the frequent repetition of information that any dietary supplement will not effectively prevent COVID-19 infection. The only nutri- 
Table 4. Changes in Eating Habits of Participants during the COVID-19 Pandemic

\begin{tabular}{lcccrrr}
\hline \multirow{2}{*}{ Eating Habits } & \multicolumn{2}{c}{ Increased } & \multicolumn{2}{c}{ Not Changed } & \multicolumn{2}{c}{ Decreased } \\
\cline { 2 - 8 } & $\mathbf{n}$ & $\%$ & $\mathbf{n}$ & $\%$ & $\mathbf{n}$ & $\%$ \\
\hline Water & 319 & 36.8 & 514 & 59.4 & 33 & 3.8 \\
Vegetables & 351 & 40.5 & 506 & 58.4 & 9 & 1.0 \\
Fruit & 425 & 49.1 & 428 & 49.4 & 13 & 1.5 \\
Red meat, chicken and fish & 278 & 32.1 & 570 & 65.8 & 18 & 2.1 \\
Dairy products & 355 & 41.0 & 507 & 58.5 & 4 & 0.5 \\
Attention to adequate-balanced nutrition & 401 & 46.3 & 438 & 50.6 & 27 & 3.1 \\
Packaged products (chips, chocolate, etc.) & 107 & 12.4 & 289 & 33.4 & 470 & 54.3 \\
Nuts (almond, walnut, etc.) & 250 & 28.9 & 573 & 66.2 & 43 & 5.0 \\
Caffeinated beverages (coffee, etc.) & 265 & 30.6 & 543 & 62.7 & 58 & 6.7 \\
Herbal tea (black, green, etc.) & 235 & 27.2 & 591 & 68.2 & 40 & 4.6 \\
Physical activity & 138 & 15.9 & 452 & 52.2 & 276 & 31.9 \\
\hline
\end{tabular}

Table 5. Changes in Food Purchasing Behavior of Participants during the COVID-19 Pandemic

\begin{tabular}{|c|c|c|c|c|c|c|}
\hline \multirow{2}{*}{ Food Purchasing Behavior } & \multicolumn{2}{|c|}{ Increased } & \multicolumn{2}{|c|}{ Not Changed } & \multicolumn{2}{|c|}{ Decreased } \\
\hline & $\mathbf{n}$ & $\%$ & $\mathbf{n}$ & $\%$ & $\mathbf{n}$ & $\%$ \\
\hline I shop for more food at one time & 557 & 64.3 & 303 & 35.0 & 6 & 0.7 \\
\hline $\begin{array}{l}\text { I use gloves while buying all foods, including fruits and } \\
\text { vegetables }\end{array}$ & 693 & 80.0 & 173 & 20.0 & - & - \\
\hline $\begin{array}{l}\text { When I buy packaged products, I pay more attention to } \\
\text { nutritional values and ingredients }\end{array}$ & 322 & 37.2 & 528 & 61.0 & 16 & 1.8 \\
\hline $\begin{array}{l}\text { Instead of buying pastries, I make them at home (bread, } \\
\text { bagels, etc.) }\end{array}$ & 605 & 69.9 & 254 & 29.3 & 7 & 0.8 \\
\hline $\begin{array}{l}\text { Instead of cooking at home, I started saying home-made } \\
\text { food with takeaway }\end{array}$ & 45 & 5.2 & 208 & 24.0 & 613 & 70.8 \\
\hline $\begin{array}{l}\text { I started using more vinegar, lemon salt, etc. to purify } \\
\text { vegetables and fruits }\end{array}$ & 514 & 59.4 & 339 & 39.1 & 13 & 1.5 \\
\hline $\begin{array}{l}\text { When I come home, I clean all the packaged with a wet } \\
\text { napkin }\end{array}$ & 610 & 70.4 & 233 & 26.9 & 23 & 2.7 \\
\hline I throw away disposable shopping bags & 534 & 61.7 & 310 & 35.8 & 22 & 2.5 \\
\hline $\begin{array}{l}\text { I keep buying products on the balcony for a while before } \\
\text { placing anywhere }\end{array}$ & 464 & 53.6 & 363 & 41.9 & 39 & 4.5 \\
\hline $\begin{array}{l}\text { I prefer branded and packaged products instead of open } \\
\text { products (milk, cheese, olives, etc.) }\end{array}$ & 511 & 59.0 & 306 & 35.3 & 49 & 5.7 \\
\hline
\end{tabular}

Table 6. Behavioral Scores of Participants

\begin{tabular}{|c|c|c|c|c|c|c|c|}
\hline \multirow{2}{*}{ Behavioral Scores } & \multicolumn{2}{|c|}{ Male } & \multicolumn{2}{|c|}{ Female } & \multicolumn{2}{|c|}{ Total } & \multirow{2}{*}{ p-value } \\
\hline & Mean \pm SD & $\operatorname{Min} / \max$ & Mean \pm SD & $\operatorname{Min} / \max$ & Mean \pm SD & $\operatorname{Min} / \max$ & \\
\hline Eating habits & $3.08 \pm 2.88$ & $-7 / 9$ & $3.50 \pm 2.64$ & $-7 / 11$ & $3.41 \pm 2.70$ & $-7 / 11$ & 0.061 \\
\hline Food purchasing & $4.91 \pm 2.87$ & $-1 / 10$ & $6.31 \pm 2.54$ & $-2 / 10$ & $6.00 \pm 2.68$ & $-2 / 10$ & 0.000 \\
\hline
\end{tabular}

Note: SD: Standard Deviation

tional supplement that has increased in use is vitamin C. Vitamin $\mathrm{C}$ is known to support the immune system and students received this basic information in health science education. ${ }^{14}$ It is thought that increasing use of supplements may be associated with the dissemination of this information because the rate of those taking nutritional supplements on their own is significantly higher than those who take it on doctors' advice.

The most important issue for the nutritional prevention of COVID-19 disease is an adequate and balanced diet to support the immune system. ${ }^{15}$ However, there are individuals who use the relationship between COVID-19 disease and nutrition to advertise and increase their own popularity by giving false information. Some current " $Z$ Generation" university students, who follow all kinds of media, may be influenced by the assertions of these individuals because they think that foods such as garlic, vinegar, sumac, and giblets can protect them from COVID19. In a similar study conducted with Chinese university students, it was determined that $42.7 \%$ of the partici- 
pants ate garlic to be protected from COVID-19.16 This researcher is unable to find any scientific study demonstrating that a single food is effective in protecting from COVID-19.

It is known that most university student diets are not nutritionally adequate or balanced during their school years. However, students typically think that an adequate and balanced diet is an important factor in the prevention of COVID-19. Therefore, in this case, they tended to increase their consumption of water, vegetables, fruits, meat, chicken, fish, and milk and other dairy products throughout the pandemic. It is assumed that changes in eating behaviors, which are described as nutritionally benefical for healthy body, derive from the idea that students educated in health sciences should be following adequate and balanced diets to prevent the disease. It is estimated that the reason for the decrease in student physical activity status is due to the higher risk of disease transmission in public areas and warnings to not go outside unless required.

There have also been major changes in student food purchasing behaviors. It is claimed that larger single-trip food purchases were necessitated by fewer out-of-home excursions, less time in public areas, possible curfews, and more consumption due to increased time spent at home. The virus can live on the surfaces of plastic, metal, wood, various fruits, and vegetables for a long time. ${ }^{17}$ Altering food purchasing behaviors (using gloves, cooking at home, ordering fewer outside products, sterilizing products, throwing bags away, keeping purchased products in an open area) stems from the knowledge that the virus can live for days. Participants also said they had increased their reading of food labels $(37.2 \%)$. It is believed that this situation is caused by a desire to go out less for shopping due to COVID-19, and that they prefer to purchase healthier and longer shelf-life foods. Similarly, university students wore masks and paid more attention to individual hygiene in the COVID-19 pandemic period. ${ }^{18}$ In a similar study questioning the knowledge, attitudes and behaviors of 592 university students about COVID-19, 64.7\% of them used face masks in their daily activities. ${ }^{15}$ In another study, almost all of the individuals $(96.2 \%)$ preferred to avoid crowded places and to wear masks when they left the house $(97.8 \%) .{ }^{19}$

\section{Conclusion}

In conclusion, the COVID-19 pandemic has significantly affected the eating and food purchasing behaviors of university students. Generally, it was observed that, since the official WHO announcement of the pandemic in March, the participants have paid more attention to adequate and balanced nutrition and preferred to stay at home as much as possible. Due to curfew restrictions, physical activities have been curtailed while food intake has increased, often more than necessary, which can be a risk factor for obesity. It is important to note that students have followed accurate and reliable sources to learn about COVID-19 in order to obtain the most accurate information. For this reason, it should be noted that statements and discourses on issues closely related to public health should have a scientific basis. People should not make any statements unless they have relevant expertise or exact knowledge on the subject.

\begin{abstract}
Abbreviations
WHO: World Health Organization; SARS-CoV: Severe Acute Respiratory Syndrome Coronavirus; MERS-CoV: Middle East Respiratory Syndrome Coronavirus; CDC: Centers for Disease Control and Prevention; BMI: Body Mass Index; SD: Standard Deviation.
\end{abstract}

Ethics Approval and Consent to Participate

This study received ethical approval from Scientific Research and Publication Ethics Commission of Gümüşhane University, Number: 2020/06, dated on June 11, 2020.

\section{Competing Interest}

Author declares that there are no significant competing financial, professional, or personal interests that might have affected the performance or presentation of the work described in this manuscript.

\section{Availability of Data and Materials}

Data collected without constraints.

\section{Authors' Contribution}

Hacı Ömer YILMAZ, Ramazan ASLAN, and Cihan UNAL created the proposal. Hac1 Ömer YILMAZ collected data from department of Nutrition and Dietetics; Ramazan ASLAN collected data from department of Emergency And Disaster Management and Cihan UNAL collected data from other departments. Hacı Ömer YILMAZ analyzed data and created the article.

\section{Acknowledgment}

Not Applicable.

\section{References}

1. Huang C, Yeming W, Xingwang L, Lili R, Jianping Z, Hu Y, et al. Clinical features of patients infected with 2019 novel coronavirus in Wuhan, China. Lancet. 2020; 395 (10223): 497-506.

2. Na Z, Dingyu Z, Wenling W, Xingwang L, Bo Y, Jingdong S, et al. A novel coronavirus from patients with pneumonia in China, 2019. The New England Journal of Medicine. 2020; 382 (8): 727-33.

3. World Health Organization. Novel coronavirus (2019-nCoV) situation report; March 2020 [cited 2020 Mar 3].

4. World Health Organization. World Health Organization DirectorGeneral's opening remarks at the media briefing on COVID-19; March 2020 [cited 2020 Mar 3].

5. Singhal T. A review of coronavirus disease-2019 (COVID-19). The Indian Journal of Pediatrics. 2020; 87 (4): 281-6. 
6. Lewis D. Mounting evidence suggests coronavirus is airborne - but health advice has not caught up. Nature. 2020 [Update 23 July 2020]; 583: 510-3.

7. Leng G, Adan RAH, Belot M, Brunstrom JM, de Graaf K, Dickson SL, et al. The determinants of food choice. Proceedings of the Nutrition Society. 2017; 76 (3): 316-27.

8. World Health Organization. Nutrition advice for adults during the COVID-19 outbreak; April 4 [cited 2020 Apr 4].

9. Centers for Disease Control and Prevention. Groups at higher risk for severe illness; April 4 [cited 2020 Apr 4].

10. Ayhan DE, Günaydin E, Gönlüaçik E, Arslan U, Çetinkaya F, Asimi H, et al. Uludağ üniversitesi tıp fakültesi öğrencilerinin beslenme alışkanlıkları ve bunları etkileyen faktörler. Uludağ Üniversitesi Tıp Fakültesi Dergisi. 2012; 38 (2): 97-104.

11. Yılmaz HÖ and Yabancı Ayhan N. Hemşirelik Öğrencilerinin bazı beslenme alışkanlıklarının değerlendirilmesi. Gümüşhane Üniversitesi Sağlık Bilimleri Dergisi. 2017; 6 (1): 17-24.

12. Ermiş E, Doğan E, Erilli N, Satici A. Üniversite Öğrencilerinin beslenme alişkanliklarinin incelenmesi: ondokuz Mayis Üniversitesi Örneği. Spor ve Performans Araştırmaları Dergisi. 2015; 6 (1): 30-40.

13. Türkiye Cumhuriyeti Yüksek Öğretim Kurulu. Koronavirüs (covid-19) bilgilendirme notu; March 2020 [cited 2020 Mar 13].
14. Carr AC and Maggini S. Vitamin $\mathrm{C}$ and immune function. Nutrients. 2017; 9 (11): 1211.

15. Türkiye Diyetisyenler Derneği. Koronavirüs Beslenme Rehberi; May 2020 [cited 2020 May 01].

16. Yang $\mathrm{H}$, Bin $\mathrm{P}, \mathrm{He} \mathrm{AJ}$. Opinions from the epicenter: an online survey of university students in Wuhan amidst the COVID-19 outbreak. Journal of Chinese Governance. 2020; 5 (2): 234-48.

17. World Health Organization. Q\&A on coronaviruses (COVID-19). How long does the virus survive on surfaces?; Apr 2020 [cited 2020 April 30].

18. Alzoubi H, Alnawaiseh N, Al-Mnayyis A, Abu-Lubad M, Aqel A, AlShagahin H. COVID-19 - knowledge attitude and practice among medical and non-medical university students in Jordan. Journal of Pure and Applied Microbiology. 2020; 14 (1): 17-24.

19. Zhong BL, Luo W, Li HM, Zhang QQ, Liu XG, Li WT, Li Y. Knowledge. attitudes, and practices towards COVID-19 among Chinese residents during the rapid rise period of the COVID-19 outbreak: a quick online cross-sectional survey. International Journal of Biological Sciences. 2020; 16 (10): 1745-52. 